DOI: $10.2478 /$ lpts-2019-0010

\title{
MODELING OF SYNERGETIC ACTION OF \\ RADIATION AND CHEMICAL POLLUTION ON THE ENVIRONMENTAL SAFETY
}

\author{
N. Remez ${ }^{1}$, A. Dychko ${ }^{1}$, L. Yevtieieva ${ }^{1}$, S. Kraychuk ${ }^{2}$, N. Ostapchuk ${ }^{2}$, J. Oliinyk $^{1}$ \\ ${ }^{1}$ Institute of Energy Saving and Energy Management, National Technical \\ University of Ukraine "Igor Sikorsky Kyiv Polytechnic Institute" \\ 37 Peremohy Ave., Kyiv, 03056, UKRAINE \\ ${ }^{2}$ Department of Economic Cybernetics, Rivne State University of Humanities \\ 12 Stepana Bandery Str., Rivne, 33000, UKRAINE
}

\begin{abstract}
The present paper provides a simple mathematical model that describes the synergistic interaction of environmental factors that occur in urban ecosystem. The model predicts the value of maximum synergistic action and the condition for its achievement, as well as implies the dependence of synergistic action on the intensity of the agents used and the proportion of irreversible damages after the combined effects. The developed mathematical model can be used to predict the accumulation of pollution in the ground layer of soil.
\end{abstract} action

Keywords: environmental safety, modelling, soil pollution, synergetic

\section{INTRODUCTION}

An important task of environmental safety is to study the effects caused by the combined impact of stress factors on living organisms, as well as the processes of their recovery and adaptation to stress influence. Under conditions of a polluted environment, it is important to know the features of simultaneous, synchronous effects of various harmful factors on organisms, the interaction of factors among themselves. The phenomenon of synergism in the interaction of different in nature stressors is a topical problem for many scientists.

A large number of concepts and theories of mathematical modelling of the combined action of two agents appeared in the 1970s-1990s. Semiempirical models based on the kinetic analysis of inactivation of cells to describe the simultaneous combination of ionizing radiation and hyperthermia were proposed [1], [2]. These models are tested only for the simplest cases where the survival curves are of an exponential nature.

Further development of kinetic approaches is associated with radiobiological identification of different cell states. Thus, Kappos A., Pohlit W. [3], [4] proposed the 
cybernetic model of radiation inactivation of cells, which became the basis for the creation of the following models of combined effects in the studies of Brannen, Jain, Pohlit, Barendsen, Curtis, Zaider, Branner [5]-[9].

One of the visual mathematical schemes of the synergistic interaction of ionizing radiation with other factors is the molecular theory of Leenhouts and Chadwick [10], [11]. This model is used to describe the combined effect of UV and $\mathrm{X}$-rays, as well as the combined action of chemical agents and ionizing radiation.

\section{EXPERIMENTAL MODELLING}

The goal of the research is to develop a mathematical model that describes the synergistic interaction of chemical and radiation contamination and its impact on the equilibrium state of ecosystems.

The main idea in mathematical modelling of synergistic effects is the changes in a cell under the action of ionizing radiation or other sub-damaging factor, which is not effective at its separate use but determines the degree and magnitude of the modification of radiosensitivity in a combined action, especially under conditions of uncertainty [12]-[14]. The effect of ionizing radiation is not only in the death of cells, but also in the fact that the macrocolonium, grown after irradiation and are visible, differ in size, morphology, period of appearance and frequency of "lethal sectors", i.e., the death of individual distant offsprings of the exposed cells in the process of macrocolon formation.

Let us consider the process of multiplication of cells as it is known in the theory of probability as the process of birth and death, then the following differential equation can be written for the average number of viable cells $n$ :

$$
\mathrm{dn} / \mathrm{dt}=\mu \mathrm{n}-\lambda \mathrm{n},
$$

where $\mu-$ the probability of cell division per unit time, $\lambda-$ the probability of cell death per time unit.

For non-irradiated cells, the probability of death is small, the solution of this equation is as follows:

$$
\mathrm{n}=\mathrm{n}_{0} \exp \left(\mu_{1} \mathrm{t}\right)
$$

where $\mu_{1}-$ the growth rate of control cells, $n_{0}-$ the initial number of cells.

For the offsprings of irradiated cells, the probability of successful division is as follows:

$$
P_{i}=(1-\alpha)^{i},
$$

where $\alpha$ - the probability of failure, i.e., the failure of cell division with one damage (hit), $i$ - the number of hits [2]. 
It should be noted that this connection - between the probability of successful division $P$ and circles and the number of hits $i-$ is similar to an exponential decrease in $P$ with an increase in the number of hits. Consequently, the rate of reproduction of remote offsprings of irradiated cells depends on the rate of reproduction of nonirradiated cells, and on the probability of failure. Then for the offsprings of survivors after irradiation of cells with one hit, it can be written:

$$
\mathrm{dn} / \mathrm{dt}=\mu_{1}(1-\alpha) \mathrm{n}-\mu_{1} \alpha \mathrm{n} .
$$

Similar dependences can be obtained for offsprings of irradiated cells with two, three or more lesions, using the dependence of the probability of successful cells division $P_{i}$ on the number of injuries $i$. The rate of reproduction of the offsprings of received irradiated cells and hits is written as follows:

$$
\mu_{\mathrm{i}}=\left[2(1-\alpha)^{\mathrm{i}}-1\right] \mu_{1} .
$$

Thus, the multiplication of remote offsprings, survived after irradiation of cells, depends on both the rate of reproduction of irradiated cells and the probability of failure.

For many of the objects and effects observed in experiments by many authors, the inhibition of recovery is not due to violation of the processes of recovery. Slowing down the speed and reducing the volume of recovery are explained by a significant increase in the proportion of irreversible damages, which make the cells unable to recover. This means that the cause of synergy is not the violation of recovery processes, but the formation of irreversible damage. Additional irreversible damages can be caused by the interaction of some non-lethal sub-damages that are formed by each agent used in the combination. Therefore, it is advisable to develop a mathematical model of synergistic interaction of various agents, taking into account the interaction of sub-damages. This model should predict the dependence of the synergistic action on the ratio of "doses" of the influencing agents, the magnitude of the maximum synergistic action and the conditions for its achievement, as well as the dependence of the synergistic action on the intensity of the used agents and the proportion of irreversible damage from which the cells are unable to recover.

Synergistic interaction means that the average amount of damage per cell is greater than if the effects are summed by each agent. Thus, under the condition of synergistic interaction, some additional damage arrives. Let us assume that additional damage at combined effects is generated through the interaction of subdamage formed after the action of each of the factors. Let us also assume that one damage from one agent interacts with one sub-damage from the other to produce one additional effective damage. Consequently, the newly created additional damage, responsible for the synergistic effect of the combined effects, is irreversible, i.e., the cells are not able to recover from such damage.

Let us also assume that each effective damage from one factor corresponds to $p_{1}$ sub-damage induced by this factor. Similarly, let us introduce the second parameter $p_{2}$ - the amount of sub-damage induced on one effective damage from the second factor. Then, assuming that the amount of effective (for example, lethal) damage 
induced by the first factor is $N_{1}$ and the second $-N_{2}$, then the total amount of subdamage generated by the first factor is equal to $p_{1} N_{1}$ and the second - to $p_{2} N_{2}$. Then the additional amount of effective $N_{3}$ sub-damage is determined by the expression:

$$
\mathrm{N}_{3}=\min \left\{\mathrm{p}_{1} \mathrm{~N}_{1} ; \mathrm{p}_{2} \mathrm{~N}_{2}\right\} .
$$

Hence, the total amount of lethal damage $N_{\Sigma}$ with the combined effect of two factors is as follows:

$$
\mathrm{N}_{\Sigma}=\mathrm{N}_{1}+\mathrm{N}_{2}+\mathrm{N}_{3}=\mathrm{N}_{1}+\mathrm{N}_{2}+\min \left\{\mathrm{p}_{1} \mathrm{~N}_{1} ; \mathrm{p}_{2} \mathrm{~N}_{2}\right\} .
$$

The coefficient of synergistic action, which shows the ratio of the amount of effective damage in the case of a combined action to the amount of damage, expected in the sum of damage, formed by each agent, can be written in the form:

$$
k=\frac{N_{1}+N_{2}+\min \left\{p_{1} N_{1} ; p_{2} N_{2}\right\}}{N_{1}+N_{2}} .
$$

This expression describes quantitively the magnitude of synergistic action. If $p_{1} N_{1}<p_{2} N_{2}$, i.e., cells die mainly from the action of the second factor, $\min \left\{p_{1} N_{1} ; p_{2} N_{2}\right\}=p_{1} N_{1} \min \left\{p_{1} N_{1} ; p_{2} N_{2}\right\}=p_{1} N_{1}$, and then from equation (6):

$$
\begin{aligned}
& \mathrm{k}_{1}=1+\frac{\mathrm{p}_{1}}{\left(1+\mathrm{N}_{2} / \mathrm{N}_{1}\right)} . \\
& \mathrm{p}_{1}=\left(\mathrm{k}_{1}-1\right) \cdot\left(1+\mathrm{N}_{2} / \mathrm{N}_{1}\right) .
\end{aligned}
$$

Similarly, if cells die primarily from the action of the first factor, i.e., $p_{l} N_{l}>$ $p_{2} N_{2}$ and

$$
\begin{aligned}
& \min \left\{\mathrm{p}_{1} \mathrm{~N}_{1} ; \mathrm{p}_{2} \mathrm{~N}_{2}\right\}=\mathrm{p}_{2} \mathrm{~N}_{2}, \\
& \mathrm{k}_{2}=1+\frac{\mathrm{p}_{2}}{\left(1+\mathrm{N}_{1} / \mathrm{N}_{2}\right)} . \\
& \mathrm{p}_{2}=\left(\mathrm{k}_{2}-1\right) \cdot\left(1+\mathrm{N}_{1} / \mathrm{N}_{2}\right) .
\end{aligned}
$$

Equation (6) can be rewritten in the next form:

$$
\mathrm{k}=1+\frac{\min \left\{\mathrm{p}_{1} ; \mathrm{p}_{2} \mathrm{~N}_{2} / \mathrm{N}_{1}\right\}}{\left(1+\mathrm{N}_{2} / \mathrm{N}_{1}\right)}
$$

It is obvious that the maximum synergistic effect occurs with the maximum value of the expression $\min \left\{\mathrm{p}_{1} ; \mathrm{p}_{2} \mathrm{~N}_{2} / \mathrm{N}_{1}\right\} /\left(1+\mathrm{N}_{2} / \mathrm{N}_{1}\right)$. 
Figure 1 presents the graphs of the dependencies of the functions $\mathrm{f}_{1}=1+\mathrm{p}_{1} /\left(1+\mathrm{N}_{2} / \mathrm{N}_{1}\right)$ and $\mathrm{f}_{2}=1+\mathrm{p}_{2} \cdot \mathrm{N}_{2} / \mathrm{N}_{1} /\left(1+\mathrm{N}_{2} / \mathrm{N}_{1}\right)$ on the ratio of effective damage $\mathrm{N}_{2} / \mathrm{N}_{1}$ formed by each agent used in the combination. These functions are calculated for arbitrarily selected values $p_{1}$ and $p_{2}\left(p_{1}=3, p_{2}=2\right)$.

From Fig. 1 it can be seen that $f_{l}$ decreases and $f_{2}$ increases with an increase in $\mathrm{N}_{2} / \mathrm{N}_{1}$, and the maximum synergistic action is obtained at $f_{1}=f_{2}$, i.e.,

$$
\frac{\mathrm{p}_{1}}{1+\mathrm{N}_{2} / \mathrm{N}_{1}}=\frac{\mathrm{p}_{2} \cdot \mathrm{N}_{2} / \mathrm{N}_{1}}{1+\mathrm{N}_{2} / \mathrm{N}_{1}}
$$

After some mathematical transformations, a condition for achieving maximum synergistic interaction is obtained:

$$
\mathrm{p}_{1} \cdot \mathrm{N}_{1}=\mathrm{p}_{2} \cdot \mathrm{N}_{2} .
$$

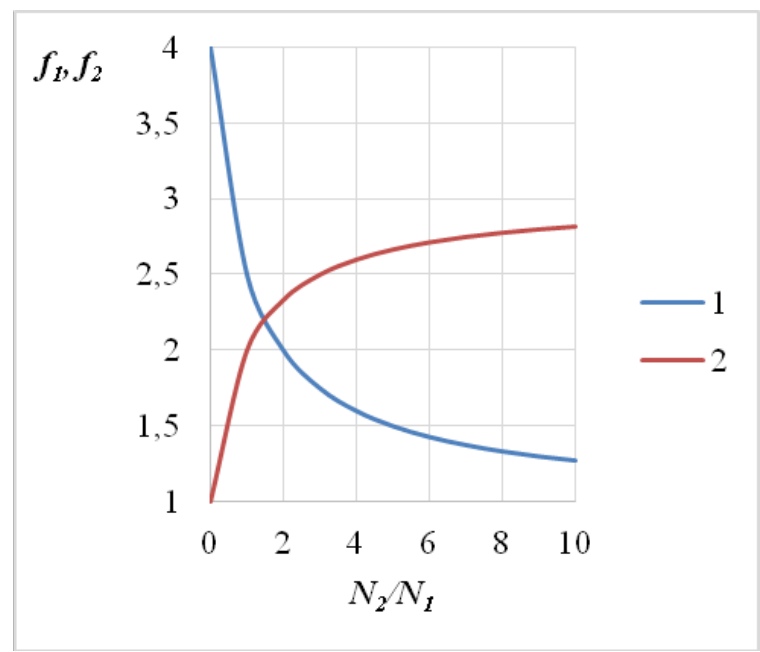

Fig. 1. Calculated dependencies of functions $f_{1}(1)$ and $f_{2}(2)$ on the ratio $\mathrm{N}_{2} / \mathrm{N}_{1}$ for arbitrarily selected parameters $p_{1}=3, p_{2}=2$.

This means that maximum synergy effect is achieved when both agents form equal amount of sub-damage. If the values of $p_{1}$ and $p_{2}$ do not differ much from one another, maximum synergy is achieved at approximately the same contributions of each agent in the researched effect. Equation (13) can be rewritten as follows:

$$
\mathrm{N}_{2} / \mathrm{N}_{1}=\mathrm{p}_{1} / \mathrm{p}_{2}
$$

Ratio $\mathrm{N}_{2} / \mathrm{N}_{1}$ can be estimated from the dose-effect curve slope ratio, for example, after the action of chemical contamination $\left(1 / t_{2}\right)$ and radiation contamination $\left(1 / t_{1}\right)$, where $t_{1}$ and $t_{2}$ - the duration of a separate action of radiation and chemical contamination that reduces survival cells in $e$ times $(e-$ the basis of natural logarithms) on the exponential sections of the dose-effect curves, i.e.: 


$$
\mathrm{N}_{2} / \mathrm{N}_{1}=\mathrm{t}_{1} / \mathrm{t}_{2}
$$

Equations (13)-(15) determine the conditions for achieving maximum synergistic interaction. Taking into account equations (6) and (4), the value of the maximum coefficient of synergistic interaction can be represented as follows:

$$
\mathrm{k}_{\max }=1+\frac{\mathrm{p}_{1} \cdot \mathrm{p}_{2}}{\mathrm{p}_{1}+\mathrm{p}_{2}}
$$

As can be seen from equation (16), $k_{\max }$ is completely determined by the values of $p_{1}$ and $p_{2}$ and does not depend on $N_{1}$ and $N_{\text {, }}$ Thus, it is possible to predict the maximum synergistic effect (16) and the ratio $\mathrm{N}_{2} / \mathrm{N}_{1}$ (13) at which it is achieved.

Using equations (8) and (10), as well as the corresponding experimental values of the synergistic amplification coefficients from two independent experiments of the combined effect, the basic parameters of the model $p_{1}$ and $p_{2}$ can be determined as the amount of sub-damage occurring in one effective damage from the agents used. Then, using equation (6), the synergistic gain for all values of $N_{1}$ and $N_{2}$ can be calculated, and by equations (13) and (16) - the maximum value of the synergistic gain and the condition in which it is achieved.

On the basis of the above-described principles of mathematical modelling of the synergistic action of several factors, a mathematical model of the effect of synergistic action of radiation and chemical pollution on the stability of ecosystems is developed, which has the following form:

$$
\left\{\begin{array}{l}
\frac{d N_{1}}{d t}=p_{1} N_{1}-\frac{p_{1}}{K_{1}} N_{1}^{2}+k_{1} N_{1} N_{2}, \\
\frac{d N_{2}}{d t}=p_{2} N_{2}-\frac{p_{2}}{K_{2}} N_{2}^{2}+k_{2} N_{1} N_{2},
\end{array}\right.
$$

where $N_{1}$ - the dose of radiation, $\mathrm{mSv} /$ year; $N_{2}$ - the concentration of harmful substance, $\mathrm{mg} / \mathrm{kg} ; p_{l}, p_{2}-$ constants of the rate of accumulation of pollution determined experimentally; $K_{l}$ - the magnitude of radioecological capacity, $\mathrm{mSv} /$ year; $K_{2}$ - the value of the extremely permissible concentration (EPC) of the harmful substance, $\mathrm{mg} / \mathrm{kg} ; k_{1,} k_{2}$ - coefficients of synergy for each component.

\section{RESULTS AND DISCUSSION}

The developed mathematical model is used to predict the synergistic effect of the ecosystem pollution in the city of Mariupol, Ukraine. Data from the Ukrainian Central Geophysical Observatory on contamination by heavy metals of soils in Mariupol in 2014-2017 (Table 1) and data from the Mariupol Hydrometeorological Observatory on the radiation background of Mariupol in 2014-2017 (Table 2) were used for calculations. 
The Content of Heavy Metals in the Soils of Mariupol in 2014-2017

\begin{tabular}{|l|c|c|c|c|}
\hline \multirow{2}{*}{ Year } & \multicolumn{3}{|c|}{ Pollutants (average / maximum, in multiplicity to norms) } \\
\cline { 2 - 5 } & $\mathrm{Cu}$ & $\mathrm{Pb}$ & $\mathrm{Zn}$ & $\mathrm{Cd}$ \\
\hline 2014 & $0.4 / 4.2$ & $1.7 / 6.5$ & $1.5 / 4.9$ & $0.1 / 0.8$ \\
\hline 2015 & $1.0 / 3.3$ & $3.5 / 36.2$ & $3.3 / 7.3$ & $0.8 / 2.5$ \\
\hline 2016 & $1.7 / 5.6$ & $4.1 / 13.1$ & $4.9 / 10.0$ & $1.8 / 3.5$ \\
\hline 2017 & $0.9 / 3.5$ & $1.3 / 8.4$ & $2.9 / 5.6$ & $2.2 / 14.5$ \\
\hline
\end{tabular}

Table 2

Radiation Background of Mariupol in 2014-2017

\begin{tabular}{|l|c|c|c|c|}
\hline & 2014 & 2015 & 2016 & 2017 \\
\hline $\mathrm{Cs}, \mathrm{mSv} /$ year & 1.052 & 1.227 & 1.14 & 0.964 \\
\hline
\end{tabular}

After the calculations, the results as graphic dependences for cesium-137 with copper, lead, zinc and cadmium were obtained (Figs. 2-5).

The figures show that the maximum synergistic effect is achieved at approximately the same contributions of each agent in the studied effect.

The greatest harmful effect on environment among the studied heavy metals is synergistic interaction of cesium-137 and cadmium, since the maximum synergy

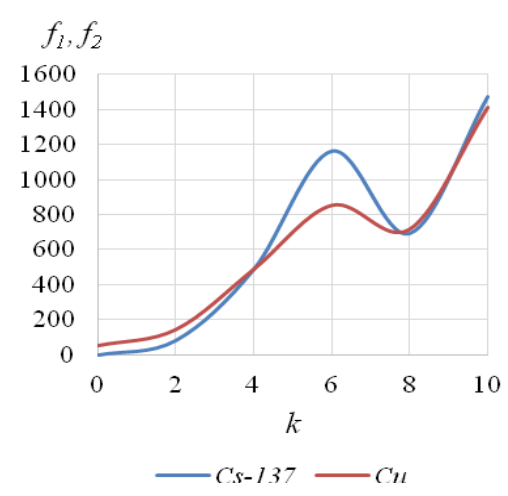

Fig. 2. Synergistic effect of $\mathrm{Cs}$ and $\mathrm{Cu}$.

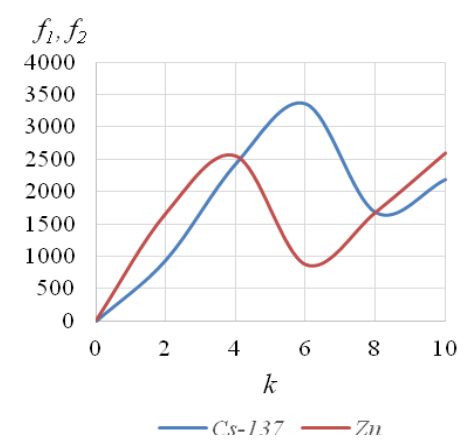

Fig. 4. Synergistic effect of $C s$ and $Z n$.

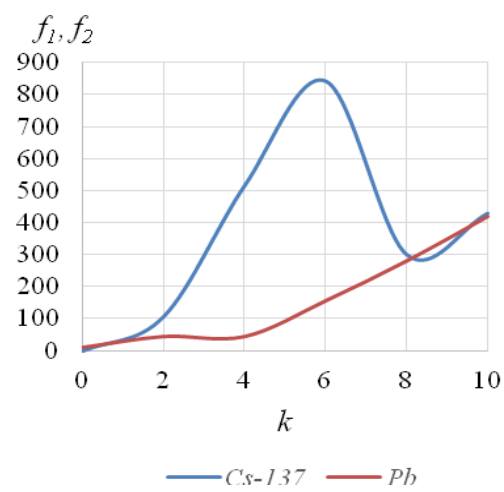

Fig. 3. Synergistic effect of $C s$ and $P b$.

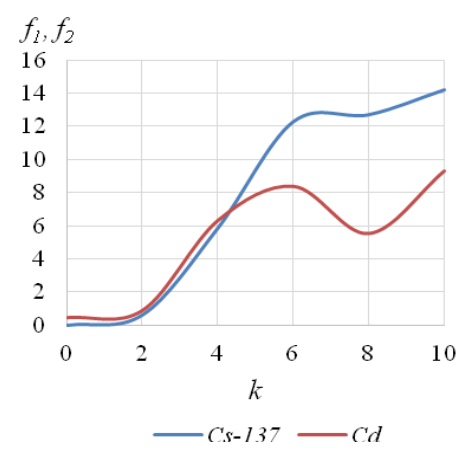

Fig. 5. Synergistic effect of $C s$ and $C d$. 
value is achieved when the cadmium EPC is exceeded by only $5 \%$. The next by harmfulness for the environment is the synergistic interaction of cesium-137 and copper in excess of copper EPC by $20 \%$ and cesium- 137 with lead - by $26.7 \%$. The least harmful among these interactions is the synergistic interaction between cesium-137 and zinc, which is achieved when the EPC is exceeded by $230 \%$.

\section{CONCLUSIONS}

The present study has introduced the developed mathematical model that describes the synergistic interaction of environmental factors that occur in the biosphere. The model predicts the value of maximum synergistic action and the condition for its achievement, as well as implies the dependence of synergistic action on the intensity of the agents used and the proportion of irreversible damages after the combined effects.

The authors of the research have developed the mathematical model used for the analysis of environmental pollution of the city. It has been established that the maximum synergistic effect is achieved at approximately the same contributions of each agent in the studied effect.

The obtained results show that the greatest harmful effect on the environment among the studied heavy metals is synergistic interaction of cesium-137 and cadmium, since the maximum synergy value is achieved with only $5 \%$ excess of cadmium EPC.

\section{REFERENCES}

1. Trujillo, R., \& Dugan, V. (1972). Synergistic inactivation of viruses by heat and ionizing radiation. Biophis. J. 12, 92-113.

2. Reynolds, M.C., \& Brannen, J.P. (1973). Thermal enhancement of radiosterilization. In Radiation Preservation of Food (pp. 165-176). Vienna: International Atomic Energy Agency.

3. Kappos, A., \& Pohlit, W. (1972). A cybernetic model for radiation reactions in living cells. I. Sparsely ionizing radiations; stationary cells. Int. J. Radiat. Biol. 22, 51-65.

4. Pohlit, W., \& Drenkard, S. (1985). Quantitative determination of the contribution of indirect and direct radiation action to the production of lethal lesions in mammalian cells. Radiation Protection Dosimetry, 13(1-4), 195-198.

5. Brannen, J.P. (1975). A temperature- and dose rate-dependent model for the kinetics of cellular response to ionising radiation. Radiat. Res., 62(3), 379-387.

6. Jain, V., \& Pohlit, W. (1986). Biocybirnetics of Cancer. Optimizing Cancer Treatment with Ionizing Radiations. Banglore: INSDOC.

7. Barendsen, G.W. (1992). Interaction of the LET dependence of radiation induced lethal and sublethal lesions in mammalian cells. Biophysical Modelling of Radiation Effects, $13-20$.

8. Curtis, S.B. (1992). Application of the LPL model to mixed radiations cells. Biophysical Modelling of Radiation Effects, 21-28.

9. Zaider, M., \& Branner, D. (1992). The application of the principle of "dual radiation action" in biophysical modelling cells. Biophysical Modelling of Radiation Effects, 3746. 
10. Leenhouts, H.P., \& Chadwick, K.H. (1978). An analysis of synergistic sensitization. Brit. J. Cancer., 37, 198-201.

11. Chadwick, K.H., \& Leenhouts, H.P. (1981). The molecular theory of radiation biology. Berlin-Heidelberg-New York: Springer Verlag.

12. Remes, N.S., \& Oliinyk Y.S. (2017). Mathematical modeling of the effect of synergistic action of chemical and radiation pollution on the stability of ecosystems. In Power Engineering. Ecology. Man. Kyiv, Ukraine: NTUU “KPI”.

13. Dychko, A., Yevtieieva, L., \& Guzovsky, M. (2014). Quality management of the environment. In Actual Problems of Management in the Modern Globalization Process. Irpen, Ukraine: National University of State Tax Service of Ukraine.

14. Dychko, A., \& Yeremeev, I. (2016). Problem of uncertainty in environmental monitoring. Systems of Information Processing, 6, 45-47.

\title{
RADIĀCIJAS UN KĪMISKĀ PIESĀRNOJUMA SINERGISKĀS IEDARBĪBAS MODELĚŠANA UZZ VIDES DROŠİ̉BU
}

\author{
N. Remezs, A. Dičko, L. Jevtejeva, S. Kraičuks, N. Ostapčuks, J. Olinik
}

$$
\text { Kopsavilkums }
$$

Rakstā sniegts vienkāršs matemātisks modelis, kas apraksta pilsētas ekosistēmā sastopamo vides faktoru sinerǵisko mijiedarbību. Modelis prognozē maksimālās sinerğiskās darbības vērtību un tās sasniegšanas nosacījumu, kā arī sinerg̣iskās darbības atkarību no izmantoto aǵentu intensitātes un neatgriezenisko bojājumu proporciju pēc kombinētās ietekmes. Izstrādāto matemātisko modeli var izmantot, lai prognozētu piesārņojuma uzkrāšanos augsnes slānī.

21.11.2018. 